\title{
DINAMIKA PERGURUAN TINGGI NUSANTARA DI TENGAH ARUS EKSPANSI PENDIDIKAN TINGGI GLOBAL
}

\author{
Yohan \\ IAIN Syaikh Abdurrahmn Siddik Bangka Belitung \\ yohan.nur.yahya@gmail.com
}

\begin{abstract}
The expansion of global higher education is convincingly beginning to seep into higher education connections in Indonesia. Foreign universities access into Indonesia will be a kind of 'contestational' and 'exotic' journey heavenly for business profits of 'global education capitalists' networks which mainly focus on two main objectives: 'teaching' and 'research'. On the contrary, it becomes a momentum for us to stimulate the development of domestic campuses in order to be more dynamic in welcoming opportunities and challenges to create and innovate relevantly to the demands and the needs of the people of Republic of Indonesia through solid coordinations and supervisions in encouraging and accelerating national development through the sense of Nusantara characters. Sooner or later, the expansive academic infiltration of global higher education is beginning to drive our higher educations to compete among the superiors. Thus, the government of Republic of Indonesia has to endorse the capability, credibility and accountability of higher education institutions through the common sense on the basic values of higher education as non-profit organization being mandated by our national constitutions and laws in intensifying community service and welfare. Make everything closer to the community, not by adopting randomly all commercial motives of global higher education which are capitalist and liberal sensed. To sum up, a set of pro-public rules, controls and policies must be strategically prepared with adequate supports based on scientific truths, benefits, reasonings, justice, virtue, affordability, honesty, sustainability, and religious responsibilities and social diversities.
\end{abstract}

Keywords: Dynamics, Tri Dharma, Academic Community, Motivation and Academic Expansion, and Globalization of Higher Education

\begin{abstract}
Abstrak
Perluasan pendidikan tinggi global secara meyakinkan mulai meresap ke dalam koneksi pendidikan tinggi di Indonesia. Akses universitas asing ke Indonesia akan menjadi semacam perjalanan 'kontroversial' dan 'eksotis' surgawi untuk keuntungan bisnis dari 'jaringan kapitalis pendidikan global' yang terutama berfokus pada dua tujuan utama: 'mengajar' dan 'penelitian'. Sebaliknya, itu menjadi momentum bagi kita untuk merangsang pengembangan kampus dalam negeri agar lebih dinamis dalam menyambut peluang dan tantangan untuk menciptakan dan berinovasi secara relevan dengan tuntutan dan kebutuhan masyarakat Republik Indonesia melalui
\end{abstract}


koordinasi yang solid dan pengawasan dalam mendorong dan mempercepat pembangunan nasional melalui rasa karakter Nusantara. Cepat atau lambat, infiltrasi akademik yang luas dari pendidikan tinggi global mulai mendorong pendidikan tinggi kita untuk bersaing di antara para atasan. Dengan demikian, pemerintah Republik Indonesia harus mengesahkan kemampuan, kredibilitas dan akuntabilitas lembaga pendidikan tinggi melalui akal sehat pada nilai-nilai dasar pendidikan tinggi sebagai organisasi nirlaba yang diamanatkan oleh konstitusi dan undang-undang nasional kita dalam mengintensifkan pelayanan masyarakat dan kesejahteraan. Jadikan segalanya lebih dekat dengan komunitas, bukan dengan mengadopsi secara acak semua motif komersial pendidikan tinggi global yang bersifat kapitalis dan liberal. Singkatnya, seperangkat aturan, kontrol, dan kebijakan pro-publik harus dipersiapkan secara strategis dengan dukungan yang memadai berdasarkan pada kebenaran ilmiah, manfaat, pertimbangan, keadilan, kebajikan, keterjangkauan, kejujuran, keberlanjutan, dan tanggung jawab agama dan keragaman sosial.

Kata Kunci : Dinamika, Tri Dharma, Komunitas Akademik, Motivasi dan Ekspansi Akademik, dan Globalisasi Pendidikan Tinggi

\section{Pendahuluan}

Tulisan ini berangkat dari salah satu tren terbaru dan pro-kontra bakal hadirnya beberapa Perguruan Tinggi Asing (PTA) ternama berkelas dunia di Indonesia yang akan meramaikan bursa Pendidikan Tinggi di Nusantara. Beberapa perguruan tinggi elit yang berancang-ancang untuk meng-internasionalisasi pendidikan tingginya di tanah air tersebut diantaranya yaitu Cambridge University yang berbasis di Inggris dengan pengaruhnya yang menggurita di sejumlah negara kemudian Melbourne University, Monash University, Central Queensland University, dan Queensland University dari Australia yang mulai mengaum membahana ke seantero dunia. Kelima perguruan tinggi papan atas tersebut merupakan sebagian dari universitas ternama di dunia yang rencananya akan membuka cabangnya di Indonesia mulai tahun 2018. ${ }^{1}$ Selain ketiga kampus tersebut diatas, beberapa kampus nge-top lainnya yang bakal beroperasi di tanah air yaitu Imperial College London yang berbasis di Inggris dengan kelas-kelas bisnis dan ekonominya yang mendunia. Kemudian ada lagi yang namanya National Taiwan University yang sedang gencar-gencarnya mencari partnership dengan salah satu kelebihannya

\footnotetext{
${ }^{1}$ Diakses tanggal 5 Juni 2018 dari http://tengokberita.com/cambridge-university-akan-buka-cabang-
} di-indonesia-tahun-ini/30 Januari/2018 
memiliki perpustakaan raksasa dengan koleksi buku mencapai 3 jutaan judul, salah satu kampus tetangga yang lokasinya tak seberapa jauh dari negara kita ${ }^{2}$. Sehingga, bagaimana daya tahan dan daya saing kompetitif yang akan dihadapi oleh para akademisi di tanah air tentunya perlu menjadi bahan pertimbangan penting.

Rencana pemerintah untuk mulai mengizinkan perguruan tinggi asing beroperasi di Indonesia telah diutarakan oleh Menteri Riset, Teknologi, dan Pendidikan Tinggi (Menristekdikti), Mohamad Nasir, pada beberapa bulan yang lalu. Nasir bahkan mengungkapkan bakal ada 5 hingga 10 universitas asing yang dalam proses pengajuan izin untuk membuka cabangnya di Indonesia. Rencana pengembangan pendidikan berskala internasional itu diharapkan bisa terwujud pada pertengahan tahun 2018 yang lalu33. "Kami memberikan kesempatan bagi perguruan tinggi asing, khususnya universitas unggulan dunia untuk beroperasi di Indonesia. Namun demikian hal tersebut jangan sampai dianggap sebagai model penjajahan gaya baru, bukan begitu karena intinya adalah kolaborasi," ujar Nasir dalam konferensi pers di Jakarta (29/1) ${ }^{4}$. Melalui kebijakan yang dikeluarkan oleh Menteri Riset dan Teknologi tersebut, maka peta persaingan akademik di perguruan tinggi akan menjadi semakin ramai dan menghebohkan. Oleh sebab itu, jika pengelolaan dan penyelenggaraan pendidikan tinggi yang nota bene-nya secara Peraturan Pemerintah sesuai dengan Undang-Undang yang perpanjangan amanahnya berada dalam wewenang Menristek Dikti yang telah mengijinkan Perguruan Tinggi Asing masuk ke Indonesia, maka bersiap-siaplah untuk memulai genderang perang globalisasi pendidikan tingkat perguruan tinggi yang akan

\footnotetext{
2 Diakses tanggal 6 Juni 2018 dari https://www.kaskus.co.id/thread//yuk-intip-profil-kampus-asingyang-bakal-masuk-indonesia/2018

3 Pendidikan antar negara merupakan transfer pendidikan dari satu negeri ke negeri lainnya; sehingga si penyaji pendidikan melakukan 'travel pendidikan' bukan antar mahasiswa melainkan antar negara. Pendidikan antar negara mendapat pembinaan dan segala hal yang berhubungan dengan instrumen pendidikan yang dibutuhkan (Garret \& Verbik, 2003a) sebagai institusi Pendidikan Tinggi dengan menyasar dan mengeksplorasi beberapa pangsa pasar baru pada negara-negara yang belum mampu bersaing pada skala yang memadai untuk menyajikan segala kebutuhan dan minat mahasiswa secara lebih kompetitif pada tingkat internasional. Diterjemahkan dan diadaptasi dari Anneke Luijten-Lub, (2007). Choices in Internationalisation: How Higher Education Institutions Respond to Internationalisation, Europeanisation and Globalisation. Czech Republik: CHEPS/UT, Postbus 217, 7500 AE Enschede.

4 Diakses tanggal 8 Juni 2018 dari https://beritagar.id/artikel/berita/pro-kontra-rencanaberoperasinya-universitas-asing/kamis/ 29 Januari/2018
} 
bergulir baik secara ilmiah maupun alamiah yang tentunya akan ada persainganpersaingan yang beragam bentuk dan rupa di dalamnya.

Disebabkan oleh ekspansi dunia industri global yang masif dalam berbagai bidang saat ini, khususnya internasionalisasi Pendidikan Tinggi yang mulai menembus batas-batas pemagar antar bangsa dan negara, maka mau tidak mau, semuanya harus siap untuk berkompetisi secara berjamaah. Dan proses laju-gerak internasionalisasi dan globalisasi pendidikan tinggi yang perlahan-lahan mulai merambat ke tanah air merupakan kelanjutan dari transformasi motivasi entah itu yang bersifat pragmatis ataukah idealis dan mungkin juga ekonomis ataukah politis berupa keinginan dan semangat untuk meningkatkan bekerjasama pedagogis dan integritas antar bangsa. ${ }^{5}$ Sehingga untuk menanggapi hal tersebut diatas, anggota Komisi X DPR RI Marlinda Poernomo mengatakan bahwa:

"Kehadiran sejumlah perguruan tinggi ternama luar negeri di Indonesia tersebut merupakan hal yang tak bisa dibendung dalam arus globalisasi. Apalagi Indonesia sudah menandatangani perjanjian perdagangan bebas dengan banyak negara di dunia. Mari kita terima semua misalnya pendidikan ataupun inovasi atau knowledge asing yang masuk ke Indonesia, tapi kita tetap menjaga dengan regulasi dengan kebijakan-kebijakan supaya bangsa Indonesia tetap mempunyai karakter yang baik. Kita memang masih membutuhkan program seperti itu, seperti di perguruan tinggi yang ada world class university dengan mengundang para professor-profesor asing ke Indonesia. Itu digunakan semata-mata untuk memberikan dorongan,"' ujar Marlinda di Komplek Parlemen DPR, Selasa $(30 / 1 / 2018)^{6}$.

Sebelum kita melanjutkan wacana hangat yang questionable diatas, sejenak mari kita ingat kembali bahwa sesungguhnya Peguruan Tinggi merupakan salah satu bentuk Non-Profit Organization. Hal tersebut, kebijakan tentang NonProfit Organization, telah tertuang dalam Peraturan Pemerintah mengenai pendirian perguruan tinggi ${ }^{7}$. Artinya, pengelolaan dan pengembangan modal serta

5 Dalam hal ini, 'internasionalisasi' bisa dimaknai sebagai proses peningkatan kerjasama dan keterhubungan antar negara. Sedangkan 'globalisasi' dipahami sebagai proses integrasi antar negara (Beerkens,2004). Diterjemahkan dan diadaptasi dari Anneke Luijten-Lub, (2007).

6 Diakses tanggal 5 Juni 2018 dari http://tengokberita.com/cambridge-university-akan-buka-cabangdi-indonesia-tahun-ini/30 Januari/2018

7 Peraturan Pemerintah Republik Indonesia Nomor 4 Tahun 2014 tentang Penyelenggaraan Pendidikan Tinggi dan Pengelolaan Perguruan Tinggi pada Bagian 3 Pasal 8 Poin 1 dan 2 berbunyi: “(1) PTN didirikan oleh Pemerintah. (2) PTS didirikan oleh masyarakat dengan membentuk Badan Penyelenggara berbadan hukum yang berprinsip nirlaba dan wajib memperoleh izin dari Menteri. 
pengerukan kekayaan dari para nasabah (users) untuk mencapai 'keuntungan komersil' bukanlah merupakan tujuan dalam pendirian dan pengelolaan pergurunan tinggi tersebut baik yang berstatus swasta maupun negeri. Hal tersebut didasarkan pada satu ciri khas yang melekat pada perguruan tinggi sebagai 'mercu suar peradaban' yang mampu mengalirkan energi keilmuan dan mengapikasikan segala temuan-temuan terkini yang bermanfaat ke seluruh persendian jejaring kehidupan yang terus bertransformasi menuju perubahan demi perubahan bagi kesejahteran bangsa dan negara melalui tiga aktifitas utama yaitu (1) pendidikan dan pengajaran, 2) penelitian dan (3) pengabdian masyarakat, sebagaimana yang tertuang dalam Tri Dharma perguruan tinggi itu sendiri ${ }^{8}$. Sehingga menjadi jelas bahwa sesungguhnya biaya yang tertampung dalam satu perguruan tinggi bukanlah untuk kepentingan bisnis dalam arti yang sesungguhnya melainkan untuk kepentingan pengelolaan dan penyelenggaraan segala aktifitas Tri Dharma Perguruan tinggi yang pada akhirnya dikembalikan lagi kepada masyarakat baik itu melalui mahasiswanya ataukah langsung kepada masyarakat itu sendiri. Jadi, sekali lagi, entah bagaimana caranya, segala bentuk profit-jika ada-tetap harus kembali dan dikembalikan lagi kepada masyarakat.

Pertanyaannya sekarang adalah akankah pendirian sejumlah Perguruan Tinggi Asing (PTA) yang bakal bercokol di tanah air siap untuk menjalankan amanah Undang-Undang sebagaimana yang tertuang kedalam tiga prinsip dasar Tri Dharma perguruan tinggi? Jika pertanyaan tersebut diajukan kepada sejumlah penyelenggara Perguruan Tinggi swasta dalam negeri, beragam respon yang ambiguitas boleh jadi akan menghiasi lembar jawaban dengan argumentasinya masing-masing. Lantas bagaimana jika pertanyaan tersebut diajukan kepada Perguruan Tinggi Asing yang akan beroperasi di Indonesia, "akankah ada jaminan penuh bahwa mereka akan berkomitmen dalam mewujudkan tiga kewajiban minimal tersebut?"

Anggap saja para jajaran akademisi yanga berasal dari Perguruan Tinggi Asing (PTA) sanggup memenuhi unsur yang pertama dan yang kedua yaitu (1) pendidikan dan pengajaran serta (2) penelitian. Lantas bagaimana dengan nasib

8 Ketiga poin pokok Tri Dharma Perguruan Tinggi tersebut merupakan Amanat Undang-Undang Republik Indonesia Nomor 12 Tahun 2012 tentang Pendidikan Tinggi yang terdapat pada Bab I Pasal 1 Poin 9. 
unsur yang ketiga, yaitu pengabdian kepada masyarakat, apakah 'naluri kemanusiaan' mereka untuk membangun masyarakat yang ada di Indonesia ini benar-benar bisa diandalkan? Jangankan orang asing, sesama orang Indonesia sendiri saja, maaf, seringkali masih perlu dipertanyakan. Sehingga manifestasi Tri Dharma di kalangan kampus yang ada ditanah airpun masih menjadi persoalan. Alih-alih untuk bersaing dengan kampus-kampus luar yang akan hadir di dalam negeri dengan semangat liberasi Pendidikan Tinggi global tersebut, untuk bersaing dengan sesama kampus dalam negeri saja masing-masing pihakpun sudah saling berjumpalitan dengan mengerahkan segenap ide, gagasan dan konsep yang terangkum dalam kepentingan dan agendanya (visi dan misi) masing-masing untuk 'mengeruk' keuntungan finansial dengan mencuri-curi peluang-peluang yang berorientasi komersial. Alih-alih rela berkorban untuk berbakti dan mengabdi kepada bangsa dan negaranya, rakyatnya sendiri saja malahan menjadi objek 'eksploitasi ilmiah' untuk kepentingan pribadi dan kelompoknya saja. inilah yang masih menjadi persoalan krusial untuk segera dibenahi dengan merujuk kembali kepada amanat Undang-Undang Republik Indonesia beserta turunannya.

Sekarang jika kita tilik kembali persoalan pokok sebelumnya tentang bakal hadirnya perguruan tinggi asing tersebut dengan merujuk merujuk kepada Undang-Undang Republik Indonesia Nomor 12 Tahun 2012 Bab VI Pasal 90 tentang Penyelenggaraan Pendidikan Tinggi oleh Lembaga negara lain, maka kebijakan yang dikeluarkan oleh pemerintah tersebut memang sudah sesuai dan selaras pada satu sisi namun pada sisi 'turunannya' masih menyisakan sejumlah celah yang bersifat debatable bahkan penetrable 9 . Sehingga pro-kontra kepentingan diantara sebagian anak bangsa dari kalangan akademisi melalui kebijakan yang sudah di-Undangkan dan ditetapkan tersebut masih menyisakan beberapa kelemahan yang masih bisa 'diutak-atik'10. Akibat sejumlah celah yang

\footnotetext{
${ }^{9}$ Bisa dilihat secara lebih terperinci dalam Undang-Undang Republik Indonesia Nomor 12 Tahun 2012 tentang Penyelenggaraan Pendidikan Tinggi oleh Lembaga Negara Lain yang terdapat pada Bab VI Pasa 190

10 Sebagaimana yang dikritisi oleh Asosiasi Perguruan Tinggi Swasta Indonesia (APTISI), Budi Djatmiko, yang dikutip oleh Suara Pembaruan (31/1/2018) dan Ketua Forum Rektor Indonesia, Suyatno (8/2/2018). Sebaliknya, salah seorang anggota Komisi X Sri Meliyana, dikutip dari situs resmi DPR RI, mengutarakan ketidaksetujuannya dengan keputusan pemerintah yang memberi izin pengoperasian kampus asing di Indonesia. Menurutnya, "Kita punya banyak cita-cita pendidikan tinggi yang tidak hanya menciptakan orang pintar dan cerdas. Tetapi anak bangsa yang bisa menjaga dan melestarikan kearifan lokal serta
} 
masih menganga disana-sini, secara tidak langsung berpeluang untuk memuluskan gerak-laju Perguruan Tinggi Asing untuk menancapkan tajinya di tanah air yang menjadikan kebijakan yang ada pada perguruan tinggi kita nampak lemah tak berdaya Beberapa celah tersebut tentunya harus segera diisi dan di-restorasi dengan solusi-solusi terkini. Oleh sebab itu, berangkat dari pendahuluan dalam tulisan ini, maka penulis tertarik untuk mendiskusikan, mendeskripsikan dan menyampaikan beberapa catatan penting seputar "Dinamika Tri Dharma Perguruan Tinggi Nusantara di Tengah Arus Ekspansi Pendidikan Tinggi Global" sebagaimana yang akan penulis uraikan pada bagian berikutnya.

\section{PEMBAHASAN}

\section{A. Dinamika Civitas Akademika dalam Dunia Pendidikan Tinggi Global}

Jika sejumlah akademisi di Peguruan Tinggi di tanah air, khususnya yang berstatus negeri, lebih berbahagia jika para mahasiswanya siap berkorban untuk menghabiskan waktunya di dalam kelas sambil melongo-longo antara takjub dan kesal (mahasiswa) mendengarkan celotehan-celotehan yang terkadang seringkali menyebalkan, maka sebagian akademisi Perguruan Tinggi Asing (PTA) menjadi lebih berbahagia jika anak didiknya memanfaatkan sebagian besar waktunya untuk berkelana secara mandiri di dalam dunia ilmiah. Melalui kegiatan yang mandiri tersebut, mereka (mahasiswa) mampu menemukan pengalaman-pengalaman keilmuan terkini serta karya-karya terbaru atau yang penulis istilahkan dengan sebutan 'autonomous scientific invention' atau 'sovereign scientific adventures' dengan harapan bisa meraih 'kepuasan ilmiah ${ }^{11}$.' Ya apanya yang hendak dielak dan ditolak, inilah adanya, penulispun menyadari sepenuhnya bahwa budaya akademik PTA yang ada di negara-negara maju telah mampu menerapkan integritas akademik yang lebih independen dengan hasil eksplorasi ilmiah yang kredibel dan akuntabel di dunia nyata. Sehingga mereka benar-benar

nasionalisme yang harus terus dipupuk." Diakses tanggal 8 Juni 2018 dari https://beritagar.id/artikel/berita/pro-kontra-rencana-beroperasinya-universitasasing/kamis/29Januari/ 2018

11 Kemampuan dalam berkarya bisa memberikan 'rasa kepuasan' tersendiri bagi pelakunya. Lihat Muthahhari, A. M. (2011). Dasar-Dasar Epistemologi Pendidikan Islam: Teori Nalar dan Pengembangan Potensi Serta Analisa Etika dalam Program Pendidikan. Bahruddin, M. [Pen]. Jakarta: Sadra International Institute. hlm. 5-17 
mampu memperoleh 'permata ilmiah' dalam dunia ilmiah modern saat ini. Suka maupun tidak suka, sebagai buktinya mereka telah mampu menguasai lapangan tengah medan iptek dan teknologi sedangkan kita hanya berada pada garis pinggirannya saja yang lebih sering hanya duduk manis di jejeran 'atribun stadion keilmuan' sebagai penonton ibarat para supporter pertandingan sepakbola piala dunia yang sangat emosional berkomentar dan berteriak antara bangga, kesal dan gregetan.

Walaupun memang tidak semua kita bisa melihat secara detail dan merasakan langsung bagaimana sepak-terjang kegairahan ilmiah para akademisi di negara-negara luar, namun setidaknya kita bisa melihat deskripsi ataupun dokumentasinya melalui sejumlah dokumenter yang sudah difilm-kan yang ada di channel-channel internet maupun melalui televisi. Atau jika kita merasa bosan menyaksikan film-film dokumenter yang direkam secara apa adanya di dunia nyata tersebut, coba kita perhatikan bagaimana alur skenario 'film-film ilmiah' yang masuk dalam daftar film-film 'Science Fiction' terbaik dunia semisal film 'The Goonies' (1985), 'Back to the Future' (1985), 'Aliens' (1986), 'Indiana Jones and The Last Crusade' (1989), 'Iron Man' (2008), 'Star Trek' (2009), 'Hugo' (2011), The Avengers' (2012), 'Gravity' (2013), 'Guardians of the Galaxy' (2014', 'Star Wars: The Last Jedi' (2017), dan lainlain. Jika belum yakin juga, maka lihat lihatlah hasil-hasil penelitian mereka dalam berbagai bidang keilmuan pada sejumlah jurnal internasional-terlepas dari segala penyalahgunaannya untuk kepentingan apa-yang sebagiannya secara nyata berkontribusi secara positif sesuai kebutuhan kehidupan umat manusia.

Jika sebagian mahasiswa PTKIN maupun PTKIS dalam negeri-'dengan kemandirian yang masih terseok-seok'-jika diberikan kebebasan eksplorasi ilmiah secara mandiri-sebagian besar waktunya habis di dunia maya hanya untuk Facebook-an, Twitter-an ataupun WhatsApp-an hingga Bigo-Bigo-an tanpa kejelasan laporan sebagaimana yang diharapkan karena ada semacam pelemparan tanggungjawab. Jika mereka tidak paham dengan materi keilmuan yang sedang mereka tekuni atau mengalami kegagalan akademik, boleh jadi 
mereka akan berjingkrak-jingkrak kesal dengan telunjuk lurus kedepan menyalahkan dosen-dosennya ataupu sebaliknya. Jika dosennya cuma menghadirkan referensi yang terbatas guna menstimulus mereka untuk rajinrajin mengunjungi perpustakaan baik yang digital maupun yang non-digital, mereka malah pura-pura kebingungan dan tidak terdorong untuk berbuat sesuatu yang lebih mandiri. Jika dosennya berhalangan hadir, sebagian dari mereka malah bersyukur, sambil kedua tanggannya menengadah keatas dengan kedua biji matanya menatap gumpalan-gumpalan awan yang memenuhi cakrawala, alhamdulillah, sambil mengucur pulang ke rumah ataupun kontrakannya atau ngacir keluyuran entah kemana. Inilah salah satu bentuk ketergantungan akademik yang masih cukup tinggi dari mahasiswa kepada para dosennya di kampus. Apakah ini salah satu bentuk kelemahan kita? Mungkin saja. Sedangkan mahasiswa yang ada di PTA lebih asik menghabiskan waktunya bagaimana menjadikan setiap momen sebagai kesempatan emas yang sangat berharga, entah itu mengisinya untuk membaca atau menulis ataupun mendesain sesuatu yang bisa dimanfaatkan sebagai karya yang bisa bermanfaat untuk orang lain. Inilah salah satu bongkahan sandungan yang masih cukup besar yang menjadi beban berat pada akademisi di kampus Nusantara ini.

Memang tidak bisa kita pungkiri bahwa sebagian besar akademisi PTA (Peguruan Tinggi Asing) dari perguruan tinggi-perguruan tinggi berkelas dunia telah berhasil-walaupun belum full 100\%-mewujudkan Tri Dharma Perguruan Tinggi bagi bangsa dan negaranya. Hal tersebut bisa dilihat dari beberapa indikator berikut ini; (1) dalam bidang pendidikan dan pengajaran mereka telah berhasil menciptakan para pembelajar yang mandiri, (2) dalam bidang penelitian mereka juga telah sukses menghasilkan temuan-temuan yang sangat spektakuler dan bermanfaat sesuai bidangnya masing-masing, bahkan (3) mereka sudah terbukti mampu menyalurkan ide dan gagasan serta solusi cemerlang bagi kemajuan dan kesejahteraan yang tentu saja, sekali lagi, untuk kepentingan bangsa dan negaranya, 'sisanya baru kemudian dikomersilkan untuk kepentingan bangsa lain'. Sehingga kait-kelindan antara tiga perbendaharaan Tri Dharma Perguruan Tinggi tersebut tampak saling 
sambung-menyambung antara penyampaian keilmuannya, pengembangan keilmuannya dan pengabdian ilmiahnya kepada bangsa dan negaranya. Itu artinya, mereka telah berhasil menciptakan akademisi-akademisi sebagai 'warga negara yang baik' bagi rakyatnya sendiri12. Lantas bagaimana dengan kita? Nampaknya segalanya memang harus masih dan segera ditata dan direstorasi kembali.

\section{B. Motivasi dan Ekspansi Akademik dalam Dunia Pendidikan Tinggi Global}

Sejak tahun lalu, Presiden RI, Jokowi, memang berencana memberi izin kepada Perguruan Tinggi Asing untuk membuka cabangnya di Indonesia. Tujuannya agar dunia pendidikan di Tanah air memiliki pembanding dalam hal kualitas. Disebabkan dalam 30 tahun terakhir belum ada terobosan yang mendasar di sektor pendidikan maka sandingan pembanding tersebut sangat dibutuhkan agar perguruan tinggi di Indonesia bisa langsung menelaah apakah sistem yang ada selama ini sudah sesuai dengan tuntutan era kekinian atau tidak. Yang menjadi penekanan penting beliau bagi universitas dalam negeri bukanlah untuk menjadi world class university akan tetapi peningkatan kontribusi secara relevan bagi pengembangan masyarakat Indonesia yang tentunya menjadi alasan utama:

"Sekali lagi kuncinya adalah relevansi dan inovasi. Jangan lagi terjebak pada rutinitas. Cara-cara baru harus dikembangkan, keinginan mahasiswa dan dosen untuk berinovasi harus ditumbuhkan, kreasi-kreasi baru harus difasilitasi dan dikembangkan. Oleh sebab itu jika tanpa diberi kompetitor sudah berubah ya nggak usah. Tapi kalau kita tunggu enggak berubah-ubah juga, ya kita beri," tutur Jokowi ${ }^{13}$.

Berangkat dari pernyataan Presiden Jokowi diatas jelas bahwa motifnya adalah untuk mengevaluasi sejauh mana tingkat perkembangan kualitas dengan bercermin dari jarak dekat dengan Perguruan Tinggi Asing (PTA) yang bakal hadir di tanah air. Motif lainnya adalah untuk menstimulus tingkat konsistensi dan relevansi inovasi yang berkontribusi positif bagi rakyat

12 Evers, et. al. (2010). A Guide to Implementing Quality Academic Service-Learning. Wisconsin Department of Public Instruction. http://dpi.wi.gov/fscp/slhmpage.html

13 Pernyataan Presiden Jokowi saat membuka Konferensi Forum Rektor Indonesia (FRI) 2018, di Universitas Hasanuddin, Makassar, Sulawesi Selatan, Kamis (15/2/2018) seperti dikutip dari Setkab. Diakses tanggal 8 Juni 2018 https://beritagar.id/artikel/berita/pancing-inovasijokowi-bisa-kasih-izin-kampus-asing. 
Indonesia melalui pengembangan kreasi-kreasi terbaru agar tercapai perubahan ke arah yang lebih baik.

Untuk ikut meramaikan perdebatan mengenai rencana pemerintah yang mengizinkan perguruan tinggi asing beroperasi di Indonesia dengan bekerja sama dengan kampus swasta dalam negeri, Wakil Presiden Jusuf Kalla, Rabu (7/2/2018) juga menyatakan bahwa:

"ada banyak manfaat yang bisa didapat oleh warga Indonesia jika kampuskampus ternama dari luar negeri beroperasi di Indonesia. Salah satunya adalah untuk mempermudah warga Indonesia untuk bisa mendapatkan pengalaman sekolah di perguruan tinggi terbaik dunia. Kemudian ia melanjutkan, sebagaimana yang dikutip oleh Beritatagar. id dari Antaranews.com; "pikirannya sederhana, kenapa kita memberikan beasiswa yang mahal-mahal untuk anak-anak kita sekolah di luar negeri? Toh tidak memakai kurikulum Indonesia, tapi kita (Pemerintah) biayai mereka triliunan yang dibiayi (lewat) LPDP (Lembaga Pengelola Dana Pendidikan). Mana yang lebih baik? Kita bawa sekolahnya ke sini sehingga lebih banyak anak yang bisa sekolah atau kita kirim mereka jauh-jauh ke luar negeri sana. Alasanya, transfer ilmu merupakan tolok ukur pembanding dalam mengembangkan dunia pendidikan di dalam negeri."14

Melalui pernyataan Jusuf Kalla tersebut diatas maka dapat dipahami bahwa motif dukungan beliau untuk menghadirkan Perguruan Tinggi Asing (PTA) adalah untuk mempercepat transfer ilmu secara lebih efisien. Hal ini tentunya memang masih bisa diterima. Mengirim para pelajar jauh-jauh ke luar negeri masih dapat terus dilakukan begitupun halnya dengan mengundang langsung narasumbernya ke dalam negeri juga bukanlah merupakan persoalan dan sah-sah saja.

Motif lain para penyelenggara negara untuk menghadiran Perguruan Tinggi Asing (PTA) beroperasi di tanah air, salah satunya adalah untuk mendorong universitas dalam negeri untuk terus membangun dan berbenahi diri, terlebih untuk meningkatkan kualitas dosen atau para pengajarnya. Meskipun demikian, Komisi X DPR RI berkeinginan agar pemerintah Indonesia terus memproteksi diri dengan sejumlah kebijakan jika perguruan tinggi asing

14 Diakses tanggal 8 Juni 2018 dari https://beritagar.id/artikel/berita/pro-kontra-rencanaberoperasinya-universitas-asing/kamis/8 Februari/2018 
tersebut tetap beroperasi sebagaimana yang dinyatakan oleh Marlinda Poernomo salah seorang anggota Komisi X DPR RI:

"Soal kehadiran perguruan tinggi Asing di Indonesia memang tidak mungkin kita bendung sedemikian rupa tapi kita harus memproteksi beberapa peraturan, kebijakan-kebijakan, regulasi yang tetap menginginkan bahwa untuk pendidikan indonesia boleh maju setara dengan negara-negara lain tetapi tetap harus mempunyai nilai-nilai keluhuran bangsa. Jadi, saya tidak antilah dengan perkembangan yang ada dari luar negeri, karena itu bisa menjadi kekuatan asalkan 'kita harus bersikap preventif' dalam menjaganya supaya nilai-nilai luhur budaya bangsa kita ini bisa terlindungi dengan baik."15

Akhirnya Indonesia kini terbuka bagi universitas asing yang ingin membuka kampusnya di Indonesia. Aliran krannya telah dibuka. "Namun demikian, kampus asing yang dibuka di tanah air bukan sekadar cabang dari universitas di luar negeri, tetapi harus memenuhi persyaratan sebagai sebuah perguruan tinggi. ${ }^{16 "}$ Demikian menurut Dirjen Pendidikan Tinggi (Dikti) Satryo Soemantri Brodjonegoro menegaskan hal ini di Jakarta, Selasa (8/1) sehubungan adanya semacam gugatan dari penyelenggara pendidikan tinggi asing yang berniat membuka cabang universitas mereka di sini, tetapi tidak mendapat izin. Mereka itu di antaranya adalah Prof. Robert J. Bignall selaku Pro Vice-Chancellor Monash University cabang Malaysia yang menilai kebijakan pendidikan tinggi di Indonesia tidak seprogresif di Malaysia. Menurut Direktorat Jenderal Dikti, Satryo, bahwa ia tidak menginginkan universitas asing di Indonesia didirikan dengan hanya menyewa ruang di sebuah perkantoran. Menurut dia, universitas yang hanya menyewa sebuah ruang di perkantoran maka tidak layak disebut sebagai universitas:

"Kalau sekadar ruang yang disewa, kan sama saja dengan kelas jarak jauh. Kami tidak ingin sebuah kampus didirikan setengah-setengah. Kalau memang mau membangun universitas, ya, total sebagai sebuah universitas yang lengkap dengan semua fasilitas yang diperlukan mahasiswa dan setiap universitas asing yang membuka kampusnya di Indonesia harus

\footnotetext{
${ }^{15}$ Diakses tanggal 5 Juni 2018 dari http://tengokberita.com/cambridge-university-akan-buka-cabangdi-indonesia-tahun-ini/30 Januari/2018

16 Persyaratan minimal pendirian satu perguruan tinggi dapat dilihat di Panduan Penyusunan Statuta Perguruan Tinggi Negeri ataupun Swasta di Kemenristek Dikti atau dapat pula dilihat di Kementerian Pendidikan dan Kementerian Agama bagi Perguruan Tinggi Islam selama tetap selaras dengan Undang-Undang dan Peraturan yang berlaku.
} 
menyesuaikan dengan budaya dan aturan yang berlaku17. Meskipun dapat menggunakan kurikulum sendiri, namun ada hal-hal tertentu yang harus tetap diikuti oleh peserta didiknya. Kemudian tentu saja mereka boleh menggunakan bahasa Inggris sebagai pengantar dalam proses belajarmengajarnya. Tetapi, mereka juga harus menyesuaikan programnya dengan kondisi dan kultur di Indonesia."18

Hemat penulis, dibalik motif pemerintah yang diwakili oleh pihak-pihak yang berwenang dalam menafsirkan dan memanifestasikan amanat UU dan keinginan para akademisi asing yang hendak mengoperasikan kampuskampus mereka, masih ada beberapa hal yang perlu dipertimbangkan. Bukan hanya persoalan manifestasi nyata Tri Dharma Perguruan Tinggi yang masih patut untuk dipersoalkan namun juga 'motif-motif internasionalisasi pendidikan tinggi' yang lainnya juga harus menjadi perhatian. Bukan tidak mungkin jika mereka juga sesungguhnya membawa agenda terselubung dengan membawa segerbong motif sosio-politik, sosio-ekonomi dan finansial ${ }^{19}$. Tidak hanya itu, ini yang lebih berbahaya, yang lebih harus diwaspadai, yaitu 'motif intelijensi,' yang kemudian malah motifnya bukan untuk menggairahkan kompetisi akademik di tanah air, malah berencana untuk mengeksploitasi 'potensi Nusantara' yang boleh jadi arus pergerakan alirannya bermuara dari dunia kampus.

Pertimbangan penulis diatas bukan tanpa alasan, salah satu indikatornya-bukan berburuk sangka namun sebagai bentuk antisipasi-coba kita perhatikan, jarang sekali kita mendengar ada perguruan tinggi kelas dunia yang mau berkompetisi di sesama negara maju, misalnya Cambridge University yang berkampus pusat di Inggris mau membuka kampus cabangnya di negeri 'Paman Sam' dengan 'Bintang David'-nya, negerinya Napoleon Bonaparte, atau

17 Di satu sisi, sistem Pendidikan Tinggi ala Barat yang sedang mendunia saat ini memang menguntungkan namun ia seringkali dilakukan tanpa pertimbangan yang matang (mengabaikan: pen.) bagi eksistensi kearifan dalam konteks lokal." Sebagaimana yang penulis terjemah dan adaptasi dari Wong \& Wu dalam Palmer, et al, [eds.]. (2011, hal. 199).

18 18Satryo Soemantri Brodjonegoro. (8 Januari 2018). Diakses tanggal 7 Juni 2018 dari htttp://perpustakaan.bappenas.go.id/Universitas/Asing/Dapat/Diri/Kampus di Indonesia

19 Proses 'internasionalisasi pendidikan tinggi' terdorong melalui semangat liberalisasi pangsa pasar pendidikan melalui inisiatif Organisasi Perdagangan Dunia atau World Trade Organisation (WTO), secara lebih khusus didasarkan oleh Kesepakatan Umum pada Perdagangan Pelayanan Jasa atau General Agreement on Trade in Services (GATS), sebagaimana yang dinyatakan oleh Van Vugh et al., (2002: 104). Diterjemahkan dan diadaptasi dari Anneke Luijten-Lub, (2007). 
negerinya Hitler si Penjagal dunia, ataupun sebaliknya Meoulbern University membuka cabangnya di negerinya Ratu Elizabeth atau di negerinya Lenin dan Carl Mark ataupun negerinya Shakespere sang pujangga ulung. Apakah karena faktor tingkat persaingan yang berpeluang sempit atau alasan pangsa pasar yang tidak mendukung, ataukah alasan lainnya? Apapun alasannya, sah-sah saja. Namun lebih daripada itu, boleh jadi bukan nilai-nilai kompetisi global yang bersemangatkan Tri Dharma Perguruan Tinggi yang mendasari motivasi akademik mereka melainkan 'ekspansi kapitalisme dan liberalisme' dengan memanfaatkan celah kelemahan negara-negara yang sedang berkembang yang berusaha mereka isi sembari mencari-cari momen yang pas bila-bila waktu untuk mendominasi dalam bentuk kolonialisasi abad modern dalam dunia Pendidikan tinggi.

Apapun motif dan seberapa besar gairah ekspansi akademik yang akan dilancarkan oleh Perguruan Tinggi Asing (PTA) beserta para agensi-agensinya yang ada di Indonesia, semuanya harus tetap berpegang kepada amanat yang prinsipil dalam Undang-Undang Republik Indonesia tentang penyelenggaraan Pendidikan Tinggi. Diantara amanat tersebut, pada Pasal 2 berbunyi: "Pendidikan Tinggi berdasarkan Pancasila, UndangUndang Dasar Negara Republik Indonesia Tahun 1945, Negara Kesatuan Republik Indonesia, dan Bhinneka Tunggal Ika." 20 Kemudian dilanjutkan pada Pasal 3 yang berbunyi: "Pendidikan Tinggi berasaskan kebenaran ilmiah, penalaran, kejujuran, keadilan, manfaat, kebajikan, tanggung jawab, kebhinnekaan, dan keterjangkauan." ${ }^{21}$ Dari amanat UU tersebut maka sudah menjadi kewajiban seluruh bangsa dan negara Indonesia untuk terus mengontrol arah dan arus pergerakan motivasi dan ekspansi akademik di tingkat perguruan tinggi. Bagaimanapun juga, segalanya harus pro-rakyat dengan tetap berpegang

20 Perubahan dalam keberagaman sosial, kaji Kahane, A.M. (2010). Power and Love: A Theory and Practice of Social Change. San Francisco. California. Berrett-Koehler Publishers, Inc

${ }^{21}$ Lihat Amanat Undang-Undang Republik Indonesia Nomor 12 Tahun 2012 tentang Pendidikan Tinggi yang terdapat pada Bab I Pasal 2 dan 3. Pertanyaan pentingnya adalah apakah mungkin semua lapisan masyarakat, khususnya masyarakat ekonomi lemah, mampu menjangkau dan menikmati proses Pendidikan Tinggi di Perguruan Tinggi Asing (PTA) tersebut ataukah mereka hanya akan menjadi penonton saja sambil melongo-longo antara kaget, sebal dan kesal? Ataukah hal tersebut hanya untuk memfasilitasi lapisan masyarakat ekonomi atas yang berekening gendut saja? 
teguh kepada konsep dasar Tri Dharma Pergurun Tinggi sebagaimana yang diamanatkan oleh Undang-Undang Negara Republik Indonesia.

\section{Dinamika Akademik di Tengah-Tengah Superioritas Pendidikan Tinggi Global}

Salah satu persoalan pokok yang biasanya seringkali dikeluh-kesahkan oleh para kalangan sivitas akademika kampus dalam negeri, baik yang negeri maupun swasta adalah segala hal yang berhubungan dengan sistem managerial dan pengorganisasian Tri Dharma Perguruan Tinggi itu sendiri. Namun yang paling mencolok ke permukaan umumnya berkenaan dengan persoalan-persoalan yang sangat individualistis yang bersifat pragmatis, klise dan berbau materi yaitu persoalan 'kesejahteraan ilmiah' alias susah berfikir kritis dan analitis jika dukungan biaya Tri Dharma Perguruan Tingginya relatif rendah sehingga berimbas kepada ketersendatan pengembangan karir akademik selanjutnya yang berujung saling antre-antrean panjang demi menjadi seorang Profesor dan kejar-kejaran sambil terengah-engah bagi yang tertinggal di buntut yang paling belakang untuk mengembangkan kelapangan karir akademik mulai dari 'asisten ahli,' 'lektor,' 'lektor kepala 'hingga menjadi 'guru besar' karena pengelolaan Tri Dharma yang bersangkutan masih kesandung kemampuan dan kemapanan dalam meneliti dan menulis kemudian mempublikasikannya. Oleh sebab itu, pengelolaan problematika yang masih menyisakan beban berat pada setiap pundak insan kampus dalam negeri inilah yang menjadi salah satu portal penghalang untuk bergerak bebas dalam percaturan persaingan global dengan para akademisi dari Perguruan Tinggi Asing (PTA) sehingga para akademisi tanah air masih nampak sangat inferior jika dihadapkan dengan para raksasa-raksasa berjubah ilmiah kelas dunia.

Disinilah salah satu persoalannya yang mesti segera dikoordinasikan sebagaimana yang telah penulis singgung diatas dan diatur kembali jangan sampai muncul ketimpangan yang sangat mencolok antara akademisi asing dengan akademisi dalam negeri. Jangan sampai mereka yang berasal dari negara asing dapat hidup makmur dan sejahtera karena alasan tradisi dan kualifikasi akademik yang mendunia sedangkan akademisi anak-anak negeri 
menjadi sakit dan menjerit-jerit karena terjepit kebijakan yang boleh jadi salah pola hingga salah kelola ${ }^{22}$. Padahal sesungguhnya kita tahu bahwa pada prinsipnya secara khusus penyelenggaraan dan pengelolaan pendidikan tinggi tanah air adalah untuk mencerdaskan dan mensejahterakan rakyat Indonesia itu sendiri guna mendorong kepentingan percepatan pengembangan dan pembangunana bangsa dan negara secara luas ${ }^{23}$. Sehingga, peran sentral Kementerian Riset dan Pendidikan Tinggi tetap harus bertanggungjawab penuh dan senantiasa hadir untuk mendampingi segenap insan kampus dalam menjalankan amanat Undang-Undang dalam proses mengatur, merencanakan, mengawasi, memantau, mengevaluasi, membina, dan mengkoordinasi penyelenggaraan pendidikan tinggi di perguruan tinggi ${ }^{24}$. Jika tanggungjawab tersebut tidak terpenuhi, maka bersiap-siaplah untuk menyaksikan akademisiakademisi kampus dalam negeri yang hanya akan menjadi pesakitan.

Melalui penjelasan diatas, satu hal yang mesti diingat, tentu saja Menristek Dikti tidak tidak terlalu ber-power jika harus bekerja sendirian untuk mengurusi segala macam 'tete-bengek' Tri Dharma kampus tanah air mulai dari Sabang hingga Merauke yang jumlahnya ribuaan mulai dari yang serius hingga yang 'ecek-ecek,' yang berkampus megah hingga yang kontrakan dan yang berada di kota-kota metropolitan dan Megapolitan hingga kota-kota kecil dan pelosok-pelosok desa. Maka disinilah peran akar rumput yang berada pada lapisan yang paling bawah yang berada dalam cakupan Kementerian Riset dan Pendidikan Tinggi untuk mulai menata kembali pengelolaan Tri Dharma Perguruan Tingginya masing-masing khususnya pengelolaan Sumber Daya Manusia yaitu tenaga kependidikannya dan yang

22 Disinilah salah satu peran penting P2MP atau LPMP sebagai bagian dari penerus wewenang sistem managerial yang ada di institusi di tingkat perguruan tinggi untuk membantu tiap-tiap dosen dalam mengatur, merencanakan, mengawasi, memantau, mengevaluasi, membina, dan mengkoordinasi penyelenggaraan Tri Dharma Perguruan Tinggi yang tentunya tetap berada dalam jaringan koordinasi dengan jajaran pimpinan pada semua level.

${ }^{23}$ Manajemen pendidikan tinggi merupakan pengelolaan perguruan tinggi secara integral dengan memanfaatkan sumber daya yang dimiliki perguruan tinggi tersebut (Bustami, 2009). Kemudian keberhasilan manajemen pendidikan tinggi dipengaruhi oleh berbagai faktor, diantaranya: kepemimpinan yang efektif (Nurdin, 2007); pendidik, peserta didik, kurikulum dan pembiayaan (Rohmad, 2004). Inti dari semua itu adalah untuk mencapai kualitas terbaik.

24 Peraturan Pemerintah Republik Indonesia Nomor 4 Tahun 2014 tentang Penyelenggaraan Pendidikan Tinggi dan Pengelolaan Perguruan Tinggi pada Bab 2 Bagian 2 Pasal 3 
terlebih lagi tenaga pendidiknya ${ }^{25}$. Tentu saja akar penopang tegaknya rumpun Tri Dharma tersebut adalah para insan akademisi itu sendiri, khususnya para dosen-dosennya ${ }^{26}$. Mampukah mereka menyerap unsur hara ilmiah yang berserakan di sekitar lapisan tanah-tanah pusaka diantara kepungan bangsa-bangsa lalu menyuplainya ke seluruh pokok, cabang, ranting, dan dedaunan yang tumbuh dan berkembang di negeri Nusantara ini atau hanya menyerap uap-uap air dari sisa-sisa embun pagi diantara bebatuan cadas yang keras hanya sekedar untuk bertahan hidup saja? Maka untuk meninggikan hingga menopang tegaknya rumpun Tri Dharma tersebut tiada jalan lain kecuali mereka harus segera menata dan mengatur kembali dudukletak dan posisinya akar tidak salah arah, bukan menghadap arah tanah yang tandus tanpa nutrisi melainkan tanah-tanah ilmiah yang subur sebagai sumber kehidupan yang menjanjikan dan menjamin keselamatan masa depan anakanak bangsa.

Secara institusional, pengelolaan kelembagaan kampus oleh sekelompok akademisi yang dilakukan secara bersama-sama meliputi beberapa unsur minimal. Adapun diantara unsur-unsur tersebut meliputi penyusunan kebijakan, pelaksanaan kegiatan akademik, pengawasan dan penjaminan mutu Tri Dharma, pengelolaan serta pengembangan akademik berupa fasilitas dan sumber-sumber belajar, dan pelaksanaan tata kelola administrasi atau tata usaha perkantoran kampus dengan pusat komando di rektoratnya masing-masing 27 . Kesemua unsur pengelolaan tersebut tentunya dapat terlaksana dengan lancar jika terkoordinasi dengan baik antara jajaran pimpinan, senat kampus, jurusan dan prodi-prodi, unit-unit pendukung, dan bagian-bagian lain-lainnya beserta para staf kependidikannya dan masyarakat umum $^{28}$. Jika tidak, maka dampaknya tentu akan berpengaruh secara

${ }^{26}$ Harus ada penguatan-penguatan dengan memperbanyak kegiatan dan mengintensifkan pengawasan dalam meningkatkan kemampuan dosen-dosen dalam mengatur 'Beban Kerjanya' masingmasing agar bebannya benar-benar tercapai, memadai dan berimbang sesuai tuntutan minimal Tri Dharma Perguruan Tinggi sebagaimana yang diamanahkan oleh Undang-Undang dan Peraturan-Peraturan yang berlaku.

27 Peraturan Pemerintah Republik Indonesia Nomor 4 Tahun 2014 tentang Penyelenggaraan Pendidikan Tinggi dan Pengelolaan Perguruan Tinggi pada Bab III Bagian 4 Pasal 28.

28 Untuk mengelola organisasi kepemimpin perguruan tinggi yang mampu memotivasi, mengkomunikasikan, dan mengambil keputusan yang tepat dengan komitmen organisasi dan 
signifikan kepada lapisan akar rumput yang paling bawah, bukan hanya para mahasiswanya saja, namun juga para dosen-dosennya. Jika cara kerja kelembagaan dalam sistem managemen kampus berproses secara tersendatsendat maka eksekusi Tri Dharma pada tiap-tiap dosen juga ikut kelimpungan yang akhirnya menjadi melambat dan begitu pula sebaliknya ${ }^{29}$. Sehingga kerja akademik yang sulit dan berat ini harus terus diperkuat dengan kordinasikoordinasi yang saling mendorong dan mengarahkan.

Pengelolaan dan Pengaturan Tri Dharma bagi tiap-tiap dosen ternyata bukanlah satu pekerjaan yang mudah. Mulai dari pengelolaan, penyelenggaraan pendidikan dan pengajaran, penelitian, pengabdian, dan juga penulisan laporan-laporan ilmiah hingga mempublikasikannya membutuhkan ketelatenan dan kecermatan yang bernalar tinggi. Meningkatkan mutu pengelolaan dan penyelenggaraan ketiga unsur Tri Dharma tersebut akan terus dituntut hingga mencapai kualitas akademik yang terbaik untuk kepentingan bangsa dan negara hingga benar-benar dapat dirasakan manfaatnya secara luas oleh masyarakat. Oleh sebab itu, jika kita merefleksi balik mengapa pemerintah akan memperkenankan masuknya perguruan Tinggi Asing berkelas dunia ini, barangkali salah satunya, adalah agar kampuskampus di tanah air dapat menjadikan mereka sebagai 'cermin hias' untuk memperbaiki 'tampilan' pendidikan tinggi kita menjadi lebih menarik, lebih apik dan lebih baik jika dipandang dan dinilai dari luar.

Jika ingin melihat bayangan Pendidikan Tinggi kita dalam kacamata global yang lebih besar-hal tersebut tidak ada salahnya-tentu kita membutuhkan cermin yang lebih besar pula untuk berkaca sewaktu-waktu ketika kita merasa wajah Pendidikan Tinggi kita nampak acak-acakan dan semrawutan. Namun harus dicatat, cermin Pendidikan Tinggi global tersebut

kerja yang efektif, silahkan lihat Candra Wijaya \& Muhammad Rifa'I. (2016). Dasar-Dasar Manajemen; Mengoptimalkan Pengelolaan Organisasi Secara Efektif dan Efesien untuk PTKIN dan PTKIS. Perdana Publishing. Medan

29 Oleh karena belum semua dosen berkualifikasi atau memilik kemampuan dan kemapanan managemen Tri Dharma Perguruan Tinggi yang baik dan paripurna untuk ketiga unsurnya, maka tidak ada salahnya jika institusi dapat memperbanyak beberapa kegiatan semacam seminar dan workshop mulai dari managemen tingkat dasar hingga berfokus kepada managemen Tri Dharma Perguruan Tinggi itu sendiri guna meningkatkan mutu akademik secara keseluruhan. 
cukup dijadikan cermin atau cerminannya saja, bukan karena keterpaksaan ${ }^{30}$. Adapun pengaturan dan penataanya seharusnya bisa kita gunakan 'salonsalon akademik' terbaik dalam negeri kita sendiri agar kita bisa mengaturnya sesuai 'cara' dan 'karakter bangsa' kita sendiri31. Hal ini dilakukan agar bangsa lain tidak mencuri-curi kesempatan dalam kesempitan untuk me-make up wajah Pendidikan Tinggi bangsa kita yang sedang ingin berbenah diri dengan caranya sendiri lalu menjadi liar dan kacau tak beraturan sebab bagaimanapun juga tentunya pendidikan tinggi kita mempusakai latar belakang historis dan jati dirinya sendiri yang berciri khas ke-Nusantaraan dalam kemajemukan. Dan jangan lupa bahwa unsur terpenting dalam pendidikan tinggi kita dinaungi dan diliputi oleh semangat ber-Ketuhanan yang Maha Esa yang masih memiliki nilai-nilai kesopanan dan kesantunan ilmiah dan alamiah dalam menjaga persatuan dan kesatuan bangsa untuk keadilan dan kesejahteraan rakyat Indonesia yang berperadaban dan berperikemanusiaan sebagaimana yang diamanahkan oleh Pancasila dan Undang-Undang Dasar 1945.

Jika menilik munculnya sejumlah kritik dan protes yang dilontarkan oleh sejumlah lembaga atas rencana kemunculan beberapa perguruan tinggi asing yang di dalamnya bertengger sejumlah akademisi kampus-khususnya para akademisi yang berasal kampus-kampus perguruan tinggi swastapenulis melihat beberapa motif yang hampir sama yang bermuara ke satu motif yaitu 'motif finansial.' Ada semacam kekhawatiran untuk berkompetisi secara lebih terbuka. Sehingga jika hal ini dihubungkan dengan kehadiran Perguruan Tinggi Asing, aroma yang tidak sedap nampak lebih tercium yang

30 Coba kita perhatikan pernyataan Jhon Taylor (2010) yang penulis kutip dalam bahasa aslinya, "Globalization is widely recognized as one of the most powerful forces for change in higher education. The term 'globalization' is commonly used by politicians keen to encourage ideas of competition and perceptions of international excellence, and by university leaders looking to foster new approaches to teaching and research. Yet there is no universally accepted definition of the term and it is widely used as a shorthand collective for a wide range of different forms of economic and social change," dalam Maringe, Felix \& Foskett, Nick. (2010). [Eds \& Conts]. Catatan, "ada beberapa kata kunci penting yang penting untuk kita maknai kembali yaitu powerful forces for change, politicians, foster new approaches to teaching and research, dan economic."

31 Kita memang perlu berfokus pada isu-isu penting seputar reformasi pendidikan yang berkelanjutan; apakah dalam bentuk budaya belajar yang sesungguhnya dan transformasi pendidikan yang bercirikan kebijaksanaan, semangat dan kesepahaman antar budaya menjadi satu realita ataukah hanya sekedar retorika belaka (Zajda: 2015, hal. 160). 
berujung kepada masalah rebut-rebutan calon mahasiswa untuk memenuhi keramaian aktifitas dalam lingkungan kampus. Maklum, jika kekurangan mahasiswa maka 'bisnis kampus' alias 'Bisnis Pendidikan Tinggi' akan sepi dan lesu karena aliran keluar-masuk keuangan berkurang bahkan boleh jadi bisa mati kelaparan sebab aliran dana tersendat karena sepi peminat. Lagi-lagi rutinitas yang bersifat finansial yang jadi pemikat.

Secara institusional, pengelolaan Tri Dharma Perguruan Tinggi di tanah air baik yang berstatus negeri maupun swasta cenderung bersifat rutinitas bukan berorientasi kualitas. Lantas bagaimana dengan dimensi pengelolaan Tri Dharma secara individual akademisi per akademisi? Jawaban terbaiknya tentunya ada pada kamus saku masing-masing. Namun demikian, banyak pihak luar beranggapan bahwa konon katanya salah satu kelemahan bangsa kita terletak pada sistem pengelolaan. Sejak dulu, menurut para agresor asing, katanya bangsa kita ini termasuk 'bangsa yang pemalas'; malas mengelola dan mengembangkan segala potensi yang ada secara konstan dan simultan namun sangat bersyahwat untuk menikmatinya secara cepat, secepat menyantap sajian 'Indomie Goreng' instan. Benarkah demikian? Kalau per-individual alias per-oknum dan perkelompok, mungkin saja. tapi jika di-generalisir, wallahu a'lam.

\section{Kesimpulan}

Dibalik tirai persaingan dan persandingan global dalam dunia Pendidikan Tinggi dewasa ini setidaknya penulis melihat ada beberapa sisi positif baik secara tersirat maupun tersurat yang bisa diambil hikmahnya. Salah satunya yaitu agar para akademisi dan juga, jika memungkinkan, masyarakat luas di tanah air bisa menyerap tradisi dan radiasi perubahan yang memancarkan cahaya kemandirian dan semangat ilmiah dari para akademisi sejumlah perguruan tinggi berkelas dunia melalui penyaringan-penyaringan dan regulasi secukupnya jangan sampai raksasa-raksasa superior tersebut menelan hiduphidup para inferior di tanah air sebab tidak semua budaya akademik yang telah atau sedang mereka lakoni tersebut cocok, pas dan pantas untuk zona katulistiwa dengan ciri khas Nusantara yang unik dan bervariasi. 
Tidak ada salahnya juga jika kita ikut termotivasi untuk mengecap dan mengenyam kemajuan yang sama dengan cita rasa yang berbeda dengan cara kita sendiri-setidaknya hampir sama seperti yang pernah atau sedang mereka nikmati saat ini-tidak melulu 'seperti ini-ini saja' secara turun-temurun sejak jaman antah-berantah. Dan hal itu bisa tercapai, salah satunya, adalah melalui gairah pergulatan interaksi dan komunikasi ilmiah dengan manusia-manusia yang berpola pikir unggul yang tersebar diantara bangsa-bangsa maju di dunia, dengan satu catatan 'jangan sampai dibodohi lagi untuk yang ke sekian kalinya dengan bentuk-bentuk ekspansi dan agresi intelektual berikut segala puspa ragam trik dan intrik kolonialisasi abad milenia dengan modusnya yang beralurliku seribu satu macam cara dan kisah.'

Dosen-dosen PTKIN maupun PTKIS khususnya, potensi dan kelebihannya masing-masing tentunya bisa diekplorasi dan dioptimalkan lagi agar menjadi semakin berkembang dan matang melalui pancaran 'pemanasan ilmiah' yang mulai mengglobal. Sekali-sekali potensi dan motivasi keilmuan dosen-dosen di PTKIN maupun PTKIS memang harus dipanasi agar tidak lembab, adem, lempem dan berbakteri. Tentu saja masih ada untungnya jika cuma berbakteri, coba jika sudah bervirus, tentu saja akan susah dicari obat penyembuh dan jamu penyehatnya karena membutuhkan biaya recovery yang sangat besar.

Maka disinilah letak strategisnya peran Rektorat sebuah kampus beserta turunannya yang diisi baik oleh tenaga pendidik maupun kependidikan yang menjadi pusat penampung, pengelola, pengembang, penyalur, dan pengarah segala bentuk aktifitas Tri Dharma Perguruan Tinggi melalui segala macam kebijakan akademik yang telah, sedang atau akan dikeluarkan. Peran ini harus dimaksimalkan untuk mengembangkan tata nilai dan tujuan akhir pengelolaan Tri Dharma pada jalur yang sesungguhnya sebagaimana yang diamanahkan oleh Pancasila, UUD 1945, Undang-Undang Negara Republik Indonesia melalui segala macam regulasi yang sedang dan yang akan dikeluarkan. Dan yang terpenting, secara individual, tiap-tiap akademisi baik tenaga pendidik maupun kependidikannya harus segera me-restrukturisasi dan meng-improvisasi kembali implementasi Tri Dharma Perguruan Tinggi agar hasilnya bisa lebih 
berkontribusi secara signifikan baik untuk mahasiswa secara khusus maupun untuk masyarakat umum secara luas.

Apapun motif dan agendanya, tentu saja setiap akademisi kampus saat ini berhak untuk berkompetisi melalui dukungan kontestan dan jaringan pasar akademiknya masing-masing. Dikarenakan adanya silang-kebutuhan ilmiah bangsa kita yang juga nampaknya semakin bergairah karena percikan serpihanserpihan kepentingan pendidikan tinggi global maka soal pro-kontra pergerakan globalisasi Pendidikan Tinggi memang agak susah untuk dibendung. Sehingga dengan membuka sedikit kran kebijakan akademik bagi dunia global di negara ini dengan tetap berpegang teguh kepada Pancasila dan UUD 1945menjadi keniscayaan yang tak terelakkan, sesuai dengan amanat UU Republik Indonesia-asalkan jangan sampai kebablasan yang alirannya pada akhirnya akan semakin kencang sehingga bertumpah-ruah membanjiri, lalu menerjang dan menenggelamkan segala keunikan dan Kebhinnekaan pendidikan tinggi Nusantara, yang sudah sejak lama tumbuh dan berkembang baik secara ilmiah maupun alamiah di kampus-kampus anak negeri.

\section{Daftar Pustaka}

Burton, A. et. all., (2008). Mission and Money; Understanding the University. United Kingdom. Cambridge: Cambridge University Press

Bustami, C. (2009). Kesan dan kenangan bersama Prof. Chairuddin P. Lubis. In H. Thaib (Ed.), Prof. Chairuddin P. Lubis dalam pandangan ulama dan cendikiawan. Medan: USU Press.

Bancin, Aswin. Managemen Perguruan Tinggi. Diakses 28 Juni 2018 dari http://doi.org/10.5281/zenodo.1095811

Evers, et. al. (2010). A Guide to Implementing Quality Academic Service-Learning. Wisconsin Department of Public Instruction. http://dpi.wi.gov/fscp/slhmpage.html.

http://tengokberita.com/cambridge-university-akan-buka-cabang-di-indonesiatahun-ini/30 Januari/2018

https://www.kaskus.co.id/thread/5a7d0937c1d770636d8b4567/yuk-intip-profilkampus-asing-yang-bakal-masuk-indonesia/ 
http://perpustakaan.bappenas.go.id/lontar/file?file=digital/blob/F19204/Universita s/Asing/DapatDiri/kan/Kampus di Indonesia.htm

https://beritagar.id/artikel/berita/pro-kontra-rencana-beroperasinya-universitasasing

https://beritagar.id/artikel/berita/pancing-inovasi-jokowi-bisa-kasih-izin-kampusasing

Kahane, A.M. (2010). Power and Love: A Theory and Practice of Social Change. San Francisco. California: Berrett-Koehler Publishers, Inc.

Luijten-Lub, Anneke. (2007). Choices in Internationalisation: How Higher Education Institutions Respond to Internationalisation, Europeanisation and Globalisation. Czech Republik. CHEPS/UT, Postbus 217, 7500 AE Enschede

Maringe, Felix \& Foskett, Nick. (2010). [Eds \& Conts]. Globalization and Internationalization in Higher Education: Theoretical, Strategic dan Management Perspectives. United Kingdom. London: Continuum International Publishing Group

Muthahhari, A. M. (2011). Dasar-Dasar Epistemologi Pendidikan Islam; Teori Nalar dan Pengembangan Potensi Serta Analisa Etika dalam Program Pendidikan. Bahruddin, M. [Pen]. Jakarta: Sadra International Institute

Nurdin, D. (2007). Manajemen pendidikan. In T. U. Indonesia, Ilmu dan aplikasi pendidikan. Jakarta. Imperial Bakti Utama

PP Republik Indonesia Nomor 4 Tahun 2014 tentang Penyelenggaraan Pendidikan Tinggi dan Pengelolaan Perguruan Tinggi. Retrived on July 18, 2018 from https://isi-ska.ac.id/pengumuman/wpcontent/uploads/2015/03/PP/No.4/2014.pdf

Permen Ristek Dikti Nomor 55 Tahun 2017: Perguruan Tinggi. Retrived on June, 28, 2018 http://bsnp-indonesia.org/wpcontent/uploads/2017/09/permenristekdikti-nomor-55-tahun-2017.pdf

Rohmad, A. (2004). Kapita selekta pendidikan. Tulung Agung: STAIN Tulung Agung

Undang-Undang Republik Indonesia Nomor 12 Tahun 2012 tentang Pendidikan Tinggi. Retrived on June, 2018 from http://diktis.kemenag.go.id/prodi/dokumen/UU-Nomor-12-Tahun-2012-ttgPendidikan-Tinggi.pdf

Wong, S. M. \& Wu, F. S. Internationalization of Higher Education in East Asia: Issues, Implication and Inquiries in Palmer, D. J, et al, (eds.), (2011). The Internationalization of East Asian Higher Education: Globalization's Impact. United State of America. Palgrave MacMillan. 
Jurnal Ilmiah Sustainable

Vol. 2 No. 1 Juni 2019, hal 46 - 69

Wijaya, Candra \& Rifa'I, Muhammad. (2016). Dasar-Dasar Manajemen; Mengoptimalkan Pengelolaan Organisasi Secara Efektif dan Efesien untuk PTKIN dan PTKIS. Medan: Perdana Publishing

Zajda, J. (2015). Globalisation, Ideology and Politics of Education Reforms in Zajda, J. (2015). (ed.). Globalization, Ideology and Politics of Education Reforms. Switzerland. Education Springer. 